\title{
Inefficiency of Indonesian Food and Beverage Firms
}

\author{
Suyanto Suyanto, Yenny Sugiarti, Olivia Tanaya \\ \{suyanto@staff.ubaya.ac.id ${ }^{1}$, yenny_s@staff.ubaya.ac.id ${ }^{2}$, oliviatanaya@staff.ubaya.ac.id\}
}

Universitas Surabaya, Jl. Raya Kalirungkut Surabaya ${ }^{1,2,3}$

\begin{abstract}
This study examines the technical inefficiency of Indonesian food and beverage firms. It also analyzes the impact of four pivotal determinants on technical inefficiency. The one-step technical efficiency model is applied to calculate the inefficiency scores of a set of unique 1,874 firms. The novelty of this study is on the homogeneity of firms under study and the additional of trade variables in the model. The findings show that the average score of technical inefficiency of Indonesian food and beverage firms is 1.52 percent. The estimation results on the key factors contributing to the inefficiency show that export, import, foreign ownership, and location are important factors in reducing the inefficiency score of firms, respectively.
\end{abstract}

Keywords: technical inefficiency, food and beverage firms, Indonesian manufacturing, export, foreign-ownership.

\section{Introduction}

Manufacturing industry remains the top contributor of the Indonesian Gross Domestic product (GDP), achieving 17,58 percent of the total production in 2019. Within the manufacturing industry, food and beverage firms contribute the largest part, accounted for 36.41 percent of the manufacturing production [1]. In term of labour absorption, food and beverage firms employ the largest proportion of employment, achieving 26.67 percent of the total labour in manufacturing industry in 2018 [2]. In addition, the firms in this sector growth significantly high at the average 7.78 percent in 2019 , considerably higher than the average growth of all industries 5.02 percent [3]. These statistical data point out the important role of food and beverage sector in the Indonesia economy. A research question arise is that whether the firms in the food and beverage sector is ready for the Industry 4.0 competition in term of efficiency. This question is break down into two minor questions; (1) which group of firms in the sector has a low inefficiency (or high efficiency); (2) what key factors significantly reduce the inefficiency of the firms so that they would be ready for the competition in Industry 4.0.

Few studies on efficiency of Indonesian manufacturing firms have been conducted. The notable among others are [4] that evaluates Indonesian manufacturing for the period 19932000 using Stochastic Frontier Analysis (SFA), [5] that estimates the technical efficiency of Indonesian manufacturing within the timeframe of 1988-2000 using another SFA method, and [6] that examines firms for period 1995-2006 using Data Envelopment Analysis (DEA). These earlier studies focus on total manufacturing firms, except [6], and have been out-dated. The use of all manufacturing firms in estimating technical efficiency has a disadvantage in heterogeneity of firms under studies, which lead to the less precision of the calculation of technical inefficiency to the best-practice firms. This current study fills the gaps and contributes twofold. 
Firstly, it focuses on firms in a specific sector of the food and beverage, which reduces the heterogeneity in data. Secondly, the period of study is updated to 2008-2014, picturing the current condition of observed firms.

This paper proceeds as follows. Section 2 reviews related literature. Methodology and data analysis is in section 3. Results and discussion are presented in section 4, followed by summary in section 5. Lastly, implication and suggestion for future research are given.

\section{Literature review}

Literature on technical efficiency of manufacturing firms comes in two streams. The first stream evaluates the technical efficiency score of firms, whereas the second stream examines the key determinants affecting the technical efficiency (or inefficiency). In the first stream, the calculation of technical efficiency focuses on either the general frontier [7]-[9], specific industry frontier [6], [10], [11], and meta frontier [12]-[14].

The second stream evaluates the key factors affecting technical inefficiency. Three pivotal factors include international trade (export and import), ownership, and location. [15] shows a significant role of import in improving efficiency of firms, whereas [16] indicates that not only import but also export are crucial in increasing efficiency score. [17] focuses on trade liberalization and found out that the ability to compete internationally is an important. Focusing on another spectrum, [18] presents evidence that ownership type is crucial in affecting technical efficiency. Similar finding is indicated in [19] when comparing foreign and local firms in Indian software industry, and in [20] when accessing ownership-heterogeneity in Italy. Furthermore, [11] highlight the importance of location. Similarly, [21] confirms the key role of location in influencing the technical efficiency of firms.

\section{Methodology and data analysis}

\subsection{Data and variables}

The main dataset for this current research is taken from the annual survey of medium and large enterprises conducted by Indonesian Central Board of Statistics (BPS). Another dataset is the wholesale price index (WPI) published by the Indonesian Central Board of Statistics and the energy price index from the ministry of energy and mineral resources.

The period of data in this study is from 2008 to 2014. The year 2008 is used as a starting year because there was a revision in the standard industrial classification (Revision 3 ISIC). The year 2014 is the latest year because there is another change in the ISIC classification. The procedure for conducting final dataset in this current study follows methods in [22]. Total number of firms in the final balanced dataset is 1,874 firms for seven years. Hence, the total observations are 13,118.

Table 1 presents the variables and their definitions. 
Table 1. Definition of Variables

\begin{tabular}{|c|c|}
\hline Variable & Definition \\
\hline Output (Y) & Value of output in Rupiah deflated using WPI at a constant price 2000. \\
\hline Material (M) & Value of material in Rupiah deflated using the WPI at a constant price 2000 \\
\hline Labour (L) & Number of fulltime equivalent employment engaged in production \\
\hline Capital (K) & Value of capital in Rupiah deflated using WPI for machinery at a constant price 2000 \\
\hline Energy (E) & $\begin{array}{l}\text { Value of energy in Rupiah, which is a sum of electricity and fuel expenditures } \\
\text { deflated using WPI for electricity and fuel price index at a constant price } 2000\end{array}$ \\
\hline $\begin{array}{l}\text { Inefficiency } \\
\text { (u) }\end{array}$ & Technical inefficiency score, which takes a value between zero and one \\
\hline Export $(\mathrm{X})$ & A dummy variable with a value one if firm exports or a value zero if otherwise. \\
\hline $\operatorname{Import}(\operatorname{Im})$ & A percentage of the value of imported material over the total value of material. \\
\hline Foreign $(\mathrm{F})$ & $\begin{array}{l}\text { A dummy variable with a value one if a firm has foreign ownership and zero } \\
\text { otherwise. }\end{array}$ \\
\hline $\begin{array}{l}\text { Location } \\
\text { (Loc) }\end{array}$ & $\begin{array}{l}\text { A dummy variable for location, which take a value of one if a firm located in Java } \\
\text { island and take a value of zero if it is located outside of Java island. }\end{array}$ \\
\hline
\end{tabular}

\subsection{Method and Model}

The method applied in this study is corresponding to the two research questions. The one-step Stochastic Frontier Analysis (SFA) estimates simultaneously stochastic production frontier and inefficiency function, which enabling for addressing the two research questions. The stochastic production frontier estimates technical efficiency score for answering the first research question, whereas the inefficiency function evaluates the key determinants affecting technical inefficiency, which addressing the second research question.

The SFA method in this current study follows the one-step [23] procedure. The advantage of one-step procedure is in the consistency of estimates and the appropriateness in model if compared with the two-step procedure.

The SFA model for this current study can be written as follows:

$$
\begin{aligned}
& Y_{i t}=\beta_{0}+\beta_{1} M_{i t}+\beta_{2} L_{i t}+\beta_{3} K_{i t}+\beta_{4} E_{i t}+\left(v_{i t}-u_{i t}\right) \\
& u_{i t}=\delta_{0}+\delta_{1} X_{i t}+\delta_{2} I m_{i t}+\delta_{3} F_{i t}+\delta_{4} L o c_{i t}+\varphi_{i t}
\end{aligned}
$$

where $\mathrm{Y}$ represents output, $\mathrm{M}$ represents material, $\mathrm{L}$ is labour, $\mathrm{K}$ is capital, $\mathrm{E}$ is energy, $\mathrm{v}$ is disturbance variable, $\mathrm{u}$ is technical efficiency, $\mathrm{X}$ is export, $\mathrm{Im}$ is import, $\mathrm{F}$ represents foreign ownership, Loc is location, $\varphi$ is disturbance variable for inefficiency function, $\beta_{0}, \beta_{1}, \beta_{2} . \beta_{3} . \beta_{4}, \delta_{0}, \delta_{1}, \delta_{2}, \delta_{3}, \delta_{4}$ are parameters to be estimated.

\section{Research results and discussion}

\subsection{Findings of technical inefficiency scores}

The estimation results for the technical efficiency score using SFA model in equations (1) and (2) are presented in Table 2. The estimation is conducted on the data of all firms as well as several important groups of firms, i.e. food versus beverage, domestic versus foreign, export versus non-exported, Java versus outside Java firms.

Finding in Table 2 shows that the average technical inefficiency score for all Food and Beverage firms is 1.52 percent. When the firms are grouped into Food industry and Beverage 
industry, one can see that the average inefficiency score of Food firms are higher than those of Beverage firms, suggesting that Food firms are more inefficient compared to Beverage firms. When the grouping is based on ownership, the estimations show that the domestic firms has an inefficiency score of 1.61 percent and foreign firms have a inefficiency score of 0 percent, indicating that domestic-owned firms are more inefficient than foreign-owned firm and that foreign-owned firms are on the best-practice level (the frontier of production). This finding in line with [18], [19]

Table 2: Technical Inefficiency of Indonesian Food and Beverage Firms (\%)

\begin{tabular}{|c|c|c|c|c|c|c|c|c|c|c|c|}
\hline Year & $\begin{array}{c}\text { Food } \\
\text { and } \\
\text { Beve } \\
\text { rage } \\
\end{array}$ & $\begin{array}{l}\text { Only } \\
\text { Food }\end{array}$ & $\begin{array}{c}\text { Only } \\
\text { Beve- } \\
\text { rage }\end{array}$ & $\begin{array}{c}\text { Dome } \\
\text { stic }\end{array}$ & $\begin{array}{c}\text { Fore- } \\
\text { ign }\end{array}$ & Export & $\begin{array}{l}\text { Not } \\
\text { Ex- } \\
\text { port }\end{array}$ & $\begin{array}{l}\text { Im- } \\
\text { port }\end{array}$ & $\begin{array}{l}\text { Not } \\
\text { Im- } \\
\text { port }\end{array}$ & Java & $\begin{array}{l}\text { Non- } \\
\text { Java }\end{array}$ \\
\hline 2008 & 1.56 & 1.59 & 1.23 & 1.63 & 0.00 & 1.17 & 1.60 & 1.01 & 1.63 & 1.96 & 0.26 \\
\hline 2009 & 1.57 & 1.59 & 1.23 & 1.64 & 0.00 & 1.19 & 1.61 & 1.03 & 1.63 & 1.96 & 0.26 \\
\hline 2010 & 1.54 & 1.56 & 1.19 & 1.60 & 0.00 & 1.12 & 1.58 & 0.99 & 1.60 & 1.93 & 0.24 \\
\hline 2011 & 1.53 & 1.55 & 1.25 & 1.60 & 0.00 & 1.06 & 1.58 & 1.00 & 1.59 & 1.92 & 0.24 \\
\hline 2012 & 1.54 & 1.57 & 1.25 & 1.62 & 0.00 & 1.23 & 1.58 & 1.04 & 1.60 & 1.93 & 0.26 \\
\hline 2013 & 1.51 & 1.53 & 1.22 & 1.58 & 0.00 & 1.22 & 1.54 & 1.02 & 1.57 & 1.90 & 0.24 \\
\hline 2014 & 1.42 & 1.44 & 1.11 & 1.57 & 0.00 & 0.90 & 1.47 & 1.01 & 1.47 & 1.79 & 0.20 \\
\hline $\begin{array}{l}\text { Ave- } \\
\text { rage }\end{array}$ & 1.52 & 1.55 & 1.21 & 1.61 & 0.00 & 1.13 & 1.56 & 1.01 & 1.58 & 1.91 & 0.24 \\
\hline $\begin{array}{l}\text { No. } \\
\text { Firms }\end{array}$ & $\begin{array}{r}187 \\
4\end{array}$ & $\begin{array}{r}173 \\
1\end{array}$ & 143 & 1793 & 81 & 1697 & 177 & 199 & $\begin{array}{r}167 \\
5\end{array}$ & $\begin{array}{r}143 \\
7\end{array}$ & 437 \\
\hline $\begin{array}{l}\text { No. } \\
\text { Obs. }\end{array}$ & $\begin{array}{r}131 \\
18\end{array}$ & $\begin{array}{r}121 \\
17\end{array}$ & 1001 & 12551 & 567 & 11879 & $\begin{array}{r}123 \\
9\end{array}$ & $\begin{array}{r}139 \\
3\end{array}$ & $\begin{array}{r}117 \\
25\end{array}$ & $\begin{array}{r}100 \\
59\end{array}$ & 3059 \\
\hline
\end{tabular}

When calculating the inefficiency score of exported versus non-exported firms, it is found that exported firms $(1.13 \%)$ have a lower inefficiency score than the non-exported firms $(1.56 \%)$. In the case of imported and non-imported firms, the technical inefficiency score for the imported firms are lower, showing that the non-imported firms are more inefficient. These findings support empirical evidence in [15], [16] that firms involves in international trade (export and import) are more efficient than those focus on domestic market.

In accessing the inefficiency score based on location, the last two columns in Table 2 show that the firms in Java region $(1.91 \%)$ have an average inefficiency higher than those outside the Java region $(0.24 \%)$. This finding should be treated carefully as the firms in Java are much more heterogeneous than those outside Java; the inefficiency scores of one firm than another have a wide dispersion. One needs to check further with a more advanced statistical method to confirm this finding. Hence, location variable is tested further in the SFA methods, as shown in the following section.

\subsection{Findings of the key determinants of technical inefficiency}

Estimation results for the determinants are presented in Table 3. This research conducts eight estimation models. The first model is for all firms in Food and Beverage industry, whereas the second and the third models are estimations on only Food firms and only Beverage firms. The other models estimates groups of firms based on the key determinants, namely ownership, export, import, and location (Java and outside Java).

Results for all firms (Model 1) shows that the production variables (material, labour, capital, and energy) are positive significant affecting output individually, which is conforms the 
empirical finding of [22]. Another point can be noted from the finding is that the sum of input elasticity is more than one, indicating Increasing Return to Scale (IRS).

Table 3. Estimation Results of Key Determinants Affecting Technical Inefficiency

\begin{tabular}{|c|c|c|c|c|c|c|c|c|}
\hline & $\begin{array}{c}\text { Food and } \\
\text { Beverage } \\
\text { (1) }\end{array}$ & $\begin{array}{l}\text { Only } \\
\text { Food } \\
(2)\end{array}$ & $\begin{array}{c}\text { Only } \\
\text { Beve- } \\
\text { rage (3) }\end{array}$ & $\begin{array}{c}\text { Domes- } \\
\text { tic } \\
(4)\end{array}$ & $\begin{array}{l}\text { Fore- } \\
\text { ign } \\
\text { (5) }\end{array}$ & $\begin{array}{c}\text { Export } \\
(6)\end{array}$ & $\begin{array}{c}\text { Import } \\
(7)\end{array}$ & $\begin{array}{c}\text { Java } \\
(\mathbf{8})\end{array}$ \\
\hline \multicolumn{9}{|c|}{ Production Frontier (Endogenous Variable: Output) } \\
\hline Const & $\begin{array}{l}3.42 * * * \\
(111.67)\end{array}$ & $\begin{array}{l}2.40 * * * \\
(51.79)\end{array}$ & $\begin{array}{l}5.87 * * * \\
(19.03)\end{array}$ & $\begin{array}{c}3.05 * * * \\
(3.21)\end{array}$ & $\begin{array}{c}3.86 * * * \\
(3.14)\end{array}$ & $\begin{array}{c}3.40 * * * \\
(54.83)\end{array}$ & $\begin{array}{c}2.19 * * * \\
(14.50)\end{array}$ & $\begin{array}{l}3.36 * * * \\
(54.73)\end{array}$ \\
\hline $\ln M$ & $\begin{array}{c}0.49 * * * \\
(1398.65)\end{array}$ & $\begin{array}{l}0.66 * * * \\
(186.25)\end{array}$ & $\begin{array}{c}0.18 * * * \\
(16.48)\end{array}$ & $\begin{array}{l}0.50 * * * \\
(1261.6)\end{array}$ & $\begin{array}{c}0.45^{* * *} \\
(22.04)\end{array}$ & $\begin{array}{l}0.49 * * * \\
(117.33)\end{array}$ & $\begin{array}{c}0.68 * * * \\
(51.09)\end{array}$ & $\begin{array}{l}0.50 * * * \\
(111.76)\end{array}$ \\
\hline $\ln L$ & $\begin{array}{l}0.37 * * * \\
(81.63)\end{array}$ & $\begin{array}{c}0.26 * * * \\
(43.01)\end{array}$ & $\begin{array}{c}0.53 * * * \\
(16.61)\end{array}$ & $\begin{array}{c}0.38 * * * \\
(5.69)\end{array}$ & $\begin{array}{l}0.34 * \\
(1.60)\end{array}$ & $\begin{array}{c}0.38 * * * \\
(46.24)\end{array}$ & $\begin{array}{l}0.22 * * * \\
(13.55)\end{array}$ & $\begin{array}{c}0.37 * * * \\
(51.02)\end{array}$ \\
\hline $\ln K$ & $\begin{array}{l}0.05 * * * \\
(13.65)\end{array}$ & $\begin{array}{c}0.03 * * * \\
(11.85)\end{array}$ & $\begin{array}{c}0.09 * * * \\
(4.61)\end{array}$ & $\begin{array}{c}0.06 * * * \\
(6.06)\end{array}$ & $\begin{array}{c}0.13 * * * \\
(4.82)\end{array}$ & $\begin{array}{c}0.49 * * * \\
(12.34)\end{array}$ & $\begin{array}{c}0.86 * * * \\
(8.68)\end{array}$ & $\begin{array}{c}0.47 * * * \\
(12.83)\end{array}$ \\
\hline $\ln \mathrm{E}$ & $\begin{array}{l}0.23 * * * \\
(77.26)\end{array}$ & $\begin{array}{c}0.16 * * * \\
(45.48)\end{array}$ & $\begin{array}{c}0.35 * * * \\
(18.38)\end{array}$ & $\begin{array}{c}0.25 * * * \\
(9.16)\end{array}$ & $\begin{array}{l}0.21 * \\
(1.38)\end{array}$ & $\begin{array}{c}0.24 * * * \\
(50,73)\end{array}$ & $\begin{array}{c}0.12 * * * \\
(8.71)\end{array}$ & $\begin{array}{c}0.23 * * * \\
(53.84)\end{array}$ \\
\hline \multicolumn{9}{|c|}{ Inefficiency Function (Endogenous Variable: Technical Inefficiency) } \\
\hline $\begin{array}{l}\text { Export } \\
\text { (X) }\end{array}$ & $\begin{array}{c}-0.05 * * * \\
(-7.90)\end{array}$ & $\begin{array}{c}- \\
0.03 * * * \\
(-2.81)\end{array}$ & $\begin{array}{l}-0.25 * * \\
(-1.89)\end{array}$ & $\begin{array}{c}- \\
0.01 * * * \\
(-3.46)\end{array}$ & $\begin{array}{c}- \\
0.15 * * * \\
(-2.10)\end{array}$ & - & $\begin{array}{l}-0.07 * \\
(1.44)\end{array}$ & $\begin{array}{c}- \\
0.18 * * * \\
(11.86)\end{array}$ \\
\hline $\begin{array}{l}\text { Import } \\
\text { (Im) }\end{array}$ & $\begin{array}{c}-0.21 * * * \\
(-6.88)\end{array}$ & $\begin{array}{c}- \\
0.21 * * * \\
(-9.95)\end{array}$ & $\begin{array}{c}-0.29 * * \\
(1.69)\end{array}$ & $\begin{array}{c}- \\
0.02 * * * \\
(9.30)\end{array}$ & $\begin{array}{c}- \\
0.42 * * * \\
(9.21)\end{array}$ & $\begin{array}{c}- \\
0.20 * * * \\
(-4.58)\end{array}$ & - & $\begin{array}{c}- \\
0.38 * * * \\
(4.22)\end{array}$ \\
\hline $\begin{array}{l}\text { Foreign } \\
\text { (F) }\end{array}$ & $\begin{array}{c}-0.33 * * * \\
(-36.75)\end{array}$ & $\begin{array}{c}- \\
0.22 * * * \\
(-15.84)\end{array}$ & $\begin{array}{c}- \\
0.51 * * * \\
(-2.09)\end{array}$ & - & - & $\begin{array}{c}- \\
0.38 * * * \\
(12.35)\end{array}$ & $\begin{array}{c}0.77 * * \\
(1.85)\end{array}$ & $\begin{array}{c}- \\
0.36 * * * \\
(3.63)\end{array}$ \\
\hline $\begin{array}{l}\text { Locatio } \\
\text { n (Loc) }\end{array}$ & $\begin{array}{c}0.27 * * * \\
(20.93)\end{array}$ & $\begin{array}{c}0.16 * * * \\
(18.35)\end{array}$ & $\begin{array}{c}0.01 \\
(0.99)\end{array}$ & $\begin{array}{c}0.14 * * * \\
(6.51)\end{array}$ & $\begin{array}{c}0.36 * * * \\
(5.76)\end{array}$ & $\begin{array}{c}0.25 * * * \\
(18.34)\end{array}$ & $\begin{array}{c}0.18 * * * \\
(4.04)\end{array}$ & - \\
\hline $\begin{array}{l}\text { Sigma- } \\
\text { squared }\end{array}$ & $\begin{array}{c}0.36 * * * \\
(30.09)\end{array}$ & $\begin{array}{c}0.20 * * * \\
(79.20)\end{array}$ & $\begin{array}{c}0.70 * * * \\
(16.17)\end{array}$ & $\begin{array}{l}0.37 * \\
(1.56)\end{array}$ & $\begin{array}{c}0.52 * * * \\
(2.34)\end{array}$ & $\begin{array}{c}0.36 * * * \\
(73.96)\end{array}$ & $\begin{array}{c}0.25 * * * \\
(24.83)\end{array}$ & $\begin{array}{c}0.30 * * * \\
(73.07)\end{array}$ \\
\hline Gamma & $\begin{array}{c}0.01 * * * \\
(8.63)\end{array}$ & $\begin{array}{c}0.01 * * * \\
(8.16)\end{array}$ & $\begin{array}{c}0.17 * * * \\
(3.21)\end{array}$ & $\begin{array}{c}0.01 * * * \\
(9.21)\end{array}$ & $\begin{array}{c}0.01 * * * \\
(6.01)\end{array}$ & $\begin{array}{c}0.01 * * * \\
(3.30)\end{array}$ & $\begin{array}{l}0.04 * \\
(1.54)\end{array}$ & $\begin{array}{c}0.19 * * * \\
(2.59)\end{array}$ \\
\hline Firms & 1,874 & 1,731 & 143 & 1,793 & 186 & 1,787 & 199 & 1,437 \\
\hline Obs & 13,118 & 12,117 & 1,001 & 12,417 & 701 & 11,633 & 1,228 & 10,059 \\
\hline
\end{tabular}

Notes: $* * *, * *$, and $*$ indicate significance at $1 \%, 5 \%$, and $10 \%$.

Source: Estimation on the final balanced dataset using equations (1) and (2) and Frontier 4.1 software.

The second part of model 1 shows the pivotal determinants of technical inefficiency. The negative significant coefficient of export indicates that the exported firms have lower inefficiency. Similarly, import is found to be negative significant affecting technical inefficiency. These findings support empirical evidence in [15], [16].

The foreign ownership is found to be negative and significant affecting technical inefficiency, suggesting a less inefficiency of foreign-owned firms compare to domestic-owned firms. As shown in the previous section, foreign firms are mostly in the frontier of production and the best-practice firms, therefore the negative significant coefficient is in line with the finding in previous section. The evidence is similar to those in [18], [19].

The location variable has a positive and significant coefficient, indicating that firms in Java region are more inefficient than those outside Java region. This finding is consistent with 
the result in the previous section, which strengthens the evidence that location is matter. Similarly, this finding in line with [11], [21]

Estimation results in Model 2 to Model 8 are similar to those in Model 1 in term of the sign and the significance of exogenous variables. Thus, the interpretation on the coefficients is similar with Model 1. The findings can be seen as robustness checks for the data, which confirm that the data are robust in several models conducted in Table 3.

\section{Summary}

This research evaluates the technical efficiency score of Indonesian food and beverage firms under various important groups. It is also examines the pivotal factors affecting technical inefficiency, namely export, import, ownership, and location. Findings in the technical inefficiency score show that food and beverage firms have an average 1.52 percent inefficiency. Findings from the pivotal factors justify that the four selected variables are important in affecting technical efficiency of food and beverage firms. Export firms are found to be less inefficiency, the increase in the percentage of imported material reduces the inefficiency score, foreign-owned firms are less inefficiency because mostly they operated as best-practice firms, and location is matter in determining firms' inefficiency. Based on these all findings, one would conclude that the groups of firms that more ready for Industry 4.0 are those involved in export and import, open to foreign investment, and located in various region in Indonesia.

\section{Implication and suggestion for future research}

The implications of this research based on the findings are threefold. Firstly, more export and import activities should be encouraged for food and beverage firms in relation to an effort to reduce technical inefficiency. Secondly, efforts in favour foreign investment could help firms in the industry to operate more efficiently. Thirdly, location decision for establishing new firms in various regions would influence the inefficiency score.

A suggestion for the future research is on the inclusion of several other variables in the analysis, such as research and development $(R \& D)$. The survey of manufacturing firms provides data on R\&D between 1994 and 1996, but after 1996 there is no longer information on R\&D. A proxy measurement might be able to use to track the $R \& D$ firms.

\section{References}

[1] Indonesian Central Board of Statistics, "Distribution of Indonesian Gross Domestic Product by Sector," 2020. [Online]. Available: https://www.bps.go.id.

[2] Indonesian Ministry of Industry, "Food and Beverage Industry as a Champion," 2020. [Online]. Available: https://kemenperin.go.id.

[3] Indonesian Central Board of Statistics, "Growth rate of Indonesian GDP on year by year basic per Sector," 2020. [Online]. Available: https://www.bps.go.id.

[4] H. Margono and S. C. Sharma, "Efficiency and productivity analyses of Indonesian manufacturing industries," J. Asian Econ., vol. 17, no. 6, pp. 979-995, 2006, doi: 10.1016/j.asieco.2006.09.004.

[5] M. Ikhsan, "Total factor productivity growth in indonesian manufacturing: A stochastic frontier approach," Glob. Econ. Rev., vol. 36, no. 4, pp. 321-342, 2007, doi: 10.1080/12265080701694488.

[6] M. Setiawan, G. Emvalomatis, and A. Oude Lansink, "The relationship between technical efficiency and industrial concentration: Evidence from the Indonesian food and beverages industry," J. Asian 
Econ., vol. 23, no. 4, pp. 466-475, 2012, doi: 10.1016/j.asieco.2012.01.002.

[7] X. Fu and Y. Gong, "Indigenous and Foreign Innovation Efforts and Drivers of Technological Upgrading: Evidence from China," World Dev., vol. 39, no. 7, pp. 1213-1225, 2011, doi: 10.1016/j.worlddev.2010.05.010.

[8] M. Lee and N. Zhang, "Technical efficiency, shadow price of carbon dioxide emissions, and substitutability for energy in the Chinese manufacturing industries," Energy Econ., vol. 34, no. 5, pp. 1492-1497, 2012, doi: 10.1016/j.eneco.2012.06.023.

[9] Z. Miao, Y. Geng, and J. Sheng, "Efficient allocation of CO2 emissions in China: A zero sum gains data envelopment model," J. Clean. Prod., vol. 112, pp. 4144-4150, 2016, doi: 10.1016/j.jclepro.2015.07.035.

[10] A. Hasanbeigi and L. Price, "A technical review of emerging technologies for energy and water efficiency and pollution reduction in the textile industry," J. Clean. Prod., vol. 95, pp. 30-44, 2015, doi: 10.1016/j.jclepro.2015.02.079.

[11] J. De Jorge-Moreno and O. R. Carrasco, "Technical efficiency and its determinants factors in Spanish textiles industry (2002-2009)," J. Econ. Stud., vol. 42, no. 3, pp. 346-357, 2015, doi: dx.doi.org/10.1108/JES-06-2013-0085.

[12] C. R. Chiu, J. L. Liou, P. I. Wu, and C. L. Fang, "Decomposition of the environmental inefficiency of the meta-frontier with undesirable output," Energy Econ., vol. 34, no. 5, pp. 1392-1399, 2012, doi: 10.1016/j.eneco.2012.06.003.

[13] C. J. Huang, T. H. Huang, and N. H. Liu, "A new approach to estimating the metafrontier production function based on a stochastic frontier framework," J. Product. Anal., vol. 42, no. 3, pp. 241-254, 2014, doi: 10.1007/s11123-014-0402-2.

[14] K. Li and B. Lin, "Metafroniter energy efficiency with $\mathrm{CO} 2$ emissions and its convergence analysis for China," Energy Econ., vol. 48, pp. 230-241, 2015, doi: 10.1016/j.eneco.2015.01.006.

[15] M. Wang and M. C. S. Wong, "International R\&D Transfer and Technical Efficiency: Evidence from Panel Study Using Stochastic Frontier Analysis,” World Dev., vol. 40, no. 10, pp. 1982-1998, 2012, doi: 10.1016/j.worlddev.2012.05.001.

[16] A. Mitra, C. Sharma, and M. A. Véganzonès-Varoudakis, "Trade liberalization, technology transfer, and firms' productive performance: The case of Indian manufacturing," J. Asian Econ., vol. 33, pp. 1-15, 2014, doi: 10.1016/j.asieco.2014.04.001.

[17] M. Kapelko and A. O. Lansink, "An international comparison of productivity change in the textile and clothing industry: a bootstrapped Malmquist index approach," Empir. Econ., vol. 48, no. 4, pp. 1499-1523, 2015, doi: 10.1007/s00181-014-0835-5.

[18] R. Servin, R. Lensink, and M. van den Berg, "Ownership and technical efficiency of microfinance institutions: Empirical evidence from Latin America," J. Bank. Financ., vol. 36, no. 7, pp. 21362144, 2012, doi: 10.1016/j.jbankfin.2012.03.018.

[19] B. K. Sahoo, B. K. Sahoo, A. Gandhi, R. Shankar, and S. R. Gangurde, “Article information :,” 2016.

[20] C. lo Storto, "Ownership structure and the technical, cost, and revenue efficiency of Italian airports," Util. Policy, vol. 50, no. January, pp. 175-193, 2018, doi: 10.1016/j.jup.2018.01.003.

[21] M. Setiawan, N. Effendi, R. Heliati, and A. S. A. Waskito, "Technical efficiency and its determinants in the Indonesian micro and small enterprises," J. Econ. Stud., vol. 46, no. 6, pp. 1157-1173, 2019.

[22] D. W. Sari, N. A. Khalifah, and S. Suyanto, "The spillover effects of foreign direct investment on the firms' productivity performances," J. Product. Anal., vol. 46, no. 2-3, pp. 199-233, 2016, doi: 10.1007/s11123-016-0484-0.

[23] T. Coelli, "Estimators and hypothesis tests for a stochastic frontier function: A Monte Carlo analysis," J. Product. Anal., vol. 6, no. 3, pp. 247-268, 1995, doi: 10.1007/BF01076978. 